\title{
Soma Maden Kazasından Sağ Kurtulan İşçilerin Travma Sonrası Stres Problemlerinin ve Psikolojik Süreçlerinin Değerlendirilmesine Yönelik Nitel Bir Araştırma
}

\author{
A Qualitative Research on the Evaluation of Posttraumatic Stress Problems and \\ Psychological Processes of Workers Survived from Soma Mine Accident
}

\section{Dr. Öğr. Üyesi Mehmed Zahid Çögenli ${ }^{1}$}

Başvuru Tarihi: 29.07.2019

Kabul Tarihi: 30.09.2019

Öz

İnsanlar hayatlarının bazı dönemlerinde karşılaştıkları kötü olaylar karşısında travma geçirebilir ve bunun bir sonucu olarak stres yaşayabilirler. Yaşanan bu stres bireyin sosyal hayatında ve iş görme becerisinde olumsuz sonuçlar doğurabilmektedir. Yapılan çalışmada Soma Maden Faciasından săg kurtarılan işçilerin yaşadıkları travma sonrasında gerek özel gerekse iş yaşamlarında karşılaştıkları zorlukları belirlemek amaçlanmıştır. Nitel araştırma yöntemi olarak planlanan çalışmada yarı yapılandırılmış sorular hazırlanarak mülakat uygulanmıştır. 13 Mayıs 2014'te Manisa'nın Soma ilçesinde meydana gelen maden kazasından kurtulan işçiler tespit edilerek görüşme için 10 adet soru hazırlanmış ve 8 kazazedeyle görüşülmüştür. Yapılan görüşme kayıtlarının incelenmesi sonucunda 8 görüşmeciden 7 tanesinde alan yazında yer yerilen travma sonrası stres bozukluğu belirtilerinin biri veya birkaçının varlı̆̆ tespit edilmiştir. Bu belirtiler uyku problemleri, aşırı uyarılmışlık hali, korku endişe kaygı durumu, travmayı hatırlatan rüyalar ve uyaranlardan kaçınma olarak belirlenmiştir. Görüşmecilerin yaşadıkları travma sonrasında aile içi problem yaşadıkları, sosyal hayatlarında adaptasyon sorunlarının baş göstermesi, tekrar iş bulmada zorlandıkları ve bunun sonucunda da ekonomik olarak zor dönemlerden geçtikleri belirlenmiştir.

Anahtar Kelimeler: Çalışma Psikolojisi, Travma Sonrası Stres Bozukluğu, İş Sağlı̆̆ı

\begin{abstract}
People may experience trauma in some periods of their lives and experience stress as a result. This stress can have negative consequences in the social life and work ability of the individual. In this study, it is aimed to determine the difficulties faced by the workers who survived the Soma Mine Disaster after the trauma they experienced in their private and work lives. In the study, which was planned as a qualitative research method, semi-structured questions were prepared and
\end{abstract}

\footnotetext{
${ }^{1}$ Uşak Üniversitesi, Sağlık Yüksekokulu, mzahid.cogenli@usak.edu.tr, ORCID: 0000-0003-3018-4157
} 
interviews were applied. On May 13, 2014, workers who survived the mine accident in Soma district of Manisa were identified and 10 questions were prepared for the interview and 8 survivors were interviewed. As a result of the interview records, 7 out of 8 interviewees were found to have one or more post traumatic stress disorder symptoms in the literature. These symptoms were determined as sleep problems, excessive arousal state, fear and anxiety state, dreams reminiscent of trauma and avoidance of stimulants. periods were determined.

Keywords: Industrial Psychology, Posttraumatic Stress Disorder, Occupational Health

\section{Giriş}

Çalışma hayatının getirdiği en temel sonuçlardan bir tanesi sosyal varlıklar olan insanların bir arada çalışmak ve üretmek zorunda kalmasıdır. Böylelikle belirli bir hedefi gerçekleştirmek için ve diğer insanların ihtiyaçlarını karşılamak adına çeşitli organizasyonlar oluşturularak bu hedeflere ulaşılmaya çalışılmıştır. Yıldırım (2019, s. 578) insanların ihtiyaçlarını karşılamak için bir arada olmak zorunluluğundan bahsederek, günümüz çalışma hayatının zorluklarının üstesinden ancak bu şekilde ve profesyonel bir yönetim anlayışla gelinebileceğini belirtmiştir. Bu yüzden çalışma hayatını birçok sektörle ele aldığımızda, insanın var olduğu her yerde ve bütün üretim süreçlerinde zorluklardan ve problemlerden söz etmek mümkündür. Bu sektörlerin bazılarında, fiziksel koşulların ve çalışma şartlarının diğerlerine göre çok daha fazla rahatsız edici, insan sağlığını tehlikeye atan ve çevresel koşullara bağlı problemlerin daha etkili olduğu bilinmektedir. Madencilik sektörü tehlikeli ve zorlayıcı işşartlarının en üst seviyede olduğu sektörlerin başında gelmektedir.

Dünya'da ve ülkemizde madencilik sektöründe yaşanan özellikle yeraltı maden sektöründe meydana gelen iş kazaları birçok insanın ölümüne sebebiyet vermiş veya iş göremez duruma getirmiştir. Bunlarla birlikte ciddi ekonomik, fizyolojik ve psikolojik sorunlara da yol açmıştır. İnsan eliyle meydana gelen ve travmaya sebebiyet verebilen bu iş kazaları çalışma hayatında önemi artarak devam eden sorunlar arasinda yer almaktadır.

Travmatik olaylar tahmin edilenin aksine toplumun büyük bir kısmını etkilemektedirler. $\mathrm{Bu}$ olaylar insan eliyle kasten yapılan, insan eliyle kazayla meydana gelen ve insandan bağımsız kendiliğinden oluşan doğal afetler şeklinde karşımıza çıkabilmektedir. Yaşanan travmanın fiziksel sonuçları olduğu gibi psikolojik ve psikososyal sonuçları da olabilmektedir. Kimileri bu süreci kendi başlarına atlatabildikleri gibi kimileri de yardım alma ihtiyacı hissedebilmektedirler. Bu süreç kişilerin sosyal ve mesleki işlevselliğinde bozulmalara sebebiyet verebilmektedir.

Araştırmanın konusu olan olay 13 Mayıs 2014 günü saat 15:10 sıralarında Soma Eynes/Karanlıkdere Kömür Ocağında meydana gelmiştir. Faciada 301 kişi hayatını kaybetmiş ve 90 kadar kişi sağ kurtulabilmiştir. Kazanın sonucunda 255 eş dul, 432 çocuk yetim kalmıştır. $\mathrm{Bu}$ araştırmada Soma maden kazasından sağ kurtulan işçilerle yüz yüze görüşülüp yaşadıkları yıkıcı travmanın sonrasında yaşamlarında ne tür sıkıntıların meydana geldiği tespit edilmeye 
çalışılmıştır. Sayısal verilerden de anlaşılacağı gibi kaza sadece maden işçilerini değil onların ailelerini, çevrelerindeki insanları, iş ve sosyal hayatlarını da etkilemiştir. Meydana gelen yıkıcı travmanın etkilerini hafifletmeyi amaçlayan Afetlerde Psikososyal Hizmetler Birliği (APHB) farklı il ve ilçelerde psikososyal destek merkezleri oluşturarak travmadan etkilenenlere yardımcı olmaya çalışmıştır. Bu çalışmada nitel araştırma yöntemi esas alınmıştır. Görüşmeler sırasında serbestlik ve esneklik sağladığı için yarı yapılandırılmış görüşme yöntemi kullanılmıştır.

\section{Travma Sonrası Stres Bozukluğu}

Travma Sonrası Stres Bozukluğu DSM-IV’ de (APA, 1994, s. 393-394) (Ruhsal bozuklukların tanısal ve sayımsal el kitabı) "Travmatik olayın arkasından bir aydan uzun süren yeniden yaşantılama, kaçınma, yabancılaşma ve aşırı uyarılmışlık gibi özgül belirtilerin ortaya çıkması ve kişinin sosyal ve mesleki işlevselliğinde bozulmaya yol açması" olarak tanımlanmaktadır. WHO (1993, s. 120), akut stres bozukluğunu ve uyum bozukluğunu şu şekilde ayırmıştır: "Travmatik olaylara karşı gösterilen bir aydan az süren tepkiler akut stres bozukluğu, bu tepkiler daha hafif olduğunda ise uyum bozukluğu olarak sınıflandırılır."

Karşılaşılan travmatik olayın doğası, şiddeti ve yaşanma biçiminin travma sonrasıstres bozukluğunun gelişiminde önemli birer role sahip olduğuayrıcakişinin daha önceden varolan bir takım yatkınlıkları ile birlikte travmatik olay yaşandıktan sonra etkisinin daha da arttığ yapılan çalışmalarla gözlemlenmiştir (Classen, Koopman ve Hales, 1998, s. 621).

Travmatik olayların ruh sağlığına etkileri eski çağlardan beri bilinmektedir. 19. yy'da şiddetli biçimde yaşanan travmaların psikolojik ve psikofizyolojik etkileri çok dikkat çekmeye başlamış ve askerlerde görülen bu etkilerinsavaşa bağlı olabileceği düşünülmüştür. Jacob DaCosta (1871) "İrritabl Kalp Üzerine" adlı çalışmasında; Amerikan iç savaşında savaşmış askerlerde çarpıntı ve göğüs ağrısı şikayetleriyle "Savaş Stres Reaksiyonu'nu” tanımlamıştır. Daha sonra bu tanıma "Asker Kalbi" ve ya "DaCosta” sendromu denmiştir. Travmaya bağlı tepkiler ilk kez 2. Dünya savaşı dönemi sonunda sınıflandırılmıştır (Hacıoğlu, Gönüllü ve Kamberya, 2002, s. 110-112). Bütün bu araştırmaların ve tanımlamaların bir ürünü olarak, travma sonrasında yaşanan belirtiler DSM-I'de (APA, 1952, s. 48-49) "Dayanılmaz Stres Reaksiyonları" olarak tanımlanmıştır. Bu tanımlamada sivil ve askeri alt tiplerinden bahsedilmiş ve hiçbir kronik forma yer verilmemiştir. DSM-II'de (APA, 1968, s. 40) ise travmaya bağlı oluşan tepkiler erişkin yaşamda uyum bozukluğu olarak tanımlanarak "Geçici Ruhsal Bozukluk" olarak adlandırılmıştır. Yapılan ilk tanımlamaların sonrasında Vietnam savaşı ve sivil afetler sonrası çalışmaların sonucu olarak DSM-III (APA, 1980, s. 236-239)'de Travma Sonrası Stres Bozukluğu, ilk kez anksiyete bozukluğu içinde yer alarak 4 kriterde tanımlanmıştır. Bunlar şu şekilde sıralanabilir:

- Travmatik olay hemen hemen herkes için ciddi sıkıntı semptomları uyandıracak şiddette olmalidir.

- Travmanın aşağıdakilerden en az biri tarafından kanıtlandığı şekilde yeniden değerlendirilmesi:

- Olayın ve mücadelelerin tekrarlayan hatırlamalarının olması,

- Olay hakkında tekrarlayan rüyalarının görülmesi, 
- Mağdurun çevresel ya da düşünceye dayalı bir uyaranla ilişkili travmatik olay tekrar ediyormuş gibi ani davranması veya hissetmesi.

- Aşağıdakilerden en az birinin görülebileceği gibi, travmadan bir süre sonra başlayarak dış dünyaya karşı duyarlılığın azalması veya dış dünyaya katılımın azalması:

- Bir veya daha fazla önemli faaliyete ilginin belirgin şekilde azalması,

- Başkalarından kopma veya yabancılaşma hissi,

- Kisitli etki.

- Travmadan önce bulunmayan aşağıdaki belirtilerden en az ikisinin görülmeye başlanması:

- Aşırı duyarlılık veya abartılı irkilme tepkisi,

- Uyku bozukluğu,

- Başkaları olmadığında hayatta kalma veya hayatta kalma için gereken davranış hakkında suçluluk,

- Hafiza kaybı veya konsantre olma sorunu,

- Travmatik olayın hatırlanmasına neden olan faaliyetlerden kaçınma,

- Travmatik olayı sembolize eden veya ona benzeyen olaylara maruz kalınması durumunda semptomların yoğunlaştırılması.

$\mathrm{Bu}$ kriterler teşhis konulmasında kullanılmak için geliştirilmiştir. Bu kriterlere ek olarak 1987’de DSM-III R ile birlikte altıncı bir belirti eklenmiştir. Bu belirtiler; psikojenik amnezi, travma ile ilgili düşüncelerden kaçınma, geleceğin yok olduğu duygusu, irritabilite ve öfkedir. Ayrıca travmatik olayın insanın yaşadığı sıradan olaylardan farklı şiddette olması gerektiği ve kaçınma belirtilerinin varlığı vurgulanmaktadır (Gersons ve Carlier, 1992, s. 744). Zamanla kitlesel savaşların sona ermesi ve yapılan araştırmalar sonucunda DSM-IV (APA, 1994, s. 393)' te farklı tipteki travmatik olayların üzerinde durulmuştur. Bunlar ölümle sonuçlanabilen ağır hastalıklar, fiziksel olmayan saldırılar, olumsuz cinsel deneyimler, çocuklarda olumsuz sonuç doğurabilen ebeveynlerin ölümü gibi stresörlerdir. DSM-V (APA, 2013, s. 265)'de Travma sonrası Stres Bozukluğunu altkümeden çıkarılmış ve ayrı bir grup olarak ele alınmıştır. Travmaya direkt maruziyet olmasa bile travmanın duyulması yoluyla da TSSB gelişebileceği vurgulanmıştır.

\section{Travmaya Bağlı Oluşan Ruhsal Bozukluklar}

Travmaya maruz kalmanın sonucunda bireyler tarafından birçok farklı tepki ortaya çıkabilmektedir. Bu farklı tepkilerin ortaya çıkmasına bireysel, toplumsal veya biyolojik faktörler, travmanın tipi, şiddeti, meydana geliş şekli etkili olabilmektedir. Bunun sonucunda da doğrudan travmayla ilişkilendirilen ve pek çok ruhsal bozukluk gelişebilmektedir. Bunlar (Akçay, 2011, s. 6-7):

1. Doğrudan travma ile ilişkilendirilen ruhsal bozukluklar:

- Akut Stres Reaksiyonu (ICD-10),

- Akut Stres bozukluğu,

- Travma Sonrası Stres Bozukluğu,

- Uyum Bozuklukları. 
2. Dolaylı olarak travma ile ilişkilendirilen ruhsal bozukluklar:

-Dissosiyatif Bozukluklar,

-Borderline Kişilik Bozuklukları,

-Konversiyon Bozuklukları,

-Somatizasyon Bozukluğu,

-Yeme Bozuklukları,

-Depresyon,

-Diğer Anksiyete Bozuklukları (yaygın anksiyete bozukluğu, panik bozukluğu, vb.),

-Psikotik Bozukluklarolarak sinıflanmaktadır.

\section{Travmaya Yol Açan Olaylar}

Travmatik olaylar 3 ana başlık altında toparlanabilir(DSM V, 2013):

a) İnsanlar tarafından bilerek ve kasten sebep olunan travmalar (tecavüz, işkence, savaş, cezaevi ve gözaltı işlemleri, terör eylemleri),

b) İnsanların istemeden sebep olduğu kaza ile sonuçlanantravmalar (uçak kazaları, trafik kazaları, gemi kazaları, iş kazaları, yangınlar),

c) Doğal afetler (sel, çı̆̆g, deprem, orman yangınları vb.).

Travma sonrası stres bozukluğunun belirtilerini travmanın türü, şiddeti, sıklığı, olayın meydana geliş şekli, bireyin yaşadığı şehrin, sosyokültürel, ekonomik, ve coğrafik özellikleri etkileyebildiği gibi kişinin cinsiyeti, varsa önceki yaşadığı travmalar, psikiyatrik öykü ve kişiye ait başa çıkma düzenekleri de etkileyebilmektedir. Travma mağdurunun travmanın öncesinde ve sonrasında yaşadığı süreç TSSB'nin klinik tablosunu şekillendirir. Bu süreç genelde beş aşamadan meydana gelir (Baysak, 2010, s. 22-23):

1. Karmaşa aşaması: Şok aşaması olarak ta isimlendirilen bu dönemde, kontrolünü kaybeden mağdur, yaşadığı travmatik olay üzerinde kontrol sağlamak için bilinçli bir çaba gösteremez. Bu süreç mağdurun travmatik olayla ilgili öznel algısıyla da ilişkili olarak güvende olduğunu hissedinceye veya travmatik olayın ilk "vuruş etkisi” geçene kadar sürmektedir.

2. Rahatlama ve şaşkınlık aşaması: Bir önceki aşamada bahsedilen "vuruş etkisi” ortadan kalktıktan sonra kişide rahatlama meydana gelir ve ardından mağdur şaşkınlık döneminde ne olduğu, neden olduğu ve olayın sonuçlarıyla ilgili yargılama süreci içerisine girer.

3. Kaçınma aşaması: Travma mağduru olayı çağrıştıran her türlü uyarandan kaçmaya çalışır ve bu yüzden sosyal ortamlardan kendini soyutlayarak iyice içine kapanır. $\mathrm{Bu}$ kaçış yoluyla kişi korku, endişe, huzursuzluk ve anksiyetesini azaltmaya çalışmaktadır.

4. Yeniden değerlendirme aşaması: $\mathrm{Bu}$ aşama mağdurun olayla yeniden yüzleştiği aşamadır. Mağdur olayın sürecini zihninde tekrar gözden geçirerek, değerlendirir ve yorumlar. Değerlendirme sonucunda olayı kendisiyle alakalı yerleşik inançlara uydurmaya çalışır. Kişinin olayı istemsizce hatırlaması ve rüyalarında görmesi aslında olayı kontrol altına almaya çalıştı̆̆ının bir göstergesidir. 
5. Uyum aşaması: Mağdurun bu son aşamaya gelebilmesi için olayı, olay sırasındaki davranışlarını ve devamında yaşadığı süreci benimsemesi gerekmektedir.

\section{Travma Sonrası Stres Tepkileri}

Yaşanan travma sonrası, kişiler bu olaylara farklı tepkiler verebilmektedir. Travma sonrası verilen tepkilerde bazı değişkenler etkilidir. Bunlar; bireysel, toplumsal ve biyolojik etkenler travmanın tipi, şiddeti, meydana geliş biçimi gibi sıralanabilir. Strese yol açan olaylara verilen tepkileri 4 başlıkta toplayabiliriz. Bunlar; fiziksel, duygusal, bilişsel ve kişilerarası tepkilerdir.

Vücudumuzda ki sempatik sinir sistemi tehlike algılandığı zaman devreye girerek kişinin tehlikeli durumdan kaçmasını veya tehlikeyle savaşması için gerekli değişikliklerin oluşmasını sağlar. Bu değişiklikler kalp atışlarında ve nefeste hızlanma, terleme kaslarda gerginlik, sindirim sisteminde hareketlilik, yorgunluk, uykuya dalmada zorluk, vücudun değişik bölgelerinde ağrı ve acı, iştahta değişiklik, mide bulantısı olarak kendisini gösterir. Bu tepkiler travmaya verilen fiziksel tepkilerdir (Baltaş ve Baltaş, 1988, s. 23-25).Travmaya verilen duygusal tepkiler ilk iki hafta sürüyorsa normal karşılanır. Şok, korku, yas, öfke, suçluluk, utanç, çaresizlik, ümitsizlik, duygusal uyuşukluk gibi yoğun duygular şekilde kendilerini gösterirler. Bir diğer tepki çeşidi olan bilişsel tepkiler duygusal tepkilerle de ilişkilidir. Gösterilen bilişsel tepkiler hem yaşanan olayın kendisi hem de gösterilen fiziksel ve duygusal tepkiler nedeniyle ortaya çıkabilirler. Söz edilen bilişsel tepkilere şaşkınlık, dalgınlık, mekân veya zamana oryantasyonunda zorlanma, hafıza problemleri ve kafa karışıklığı örnek verilebilir. Son olarak kişilerarası tepkiler yaşanan aşırı stres durumlarında evde, okulda veya işteki arkadaşlıkta, evlilik ve ebeveynlik ilişkilerinde bir takım değişiklikler ortaya çıkarabilir. İlişskilerde yaşanan bu değişiklikler tedirginlik, güvensizlik, artan çatışma eğilimi, içe kapanma, yalnız kalma, kendini reddedilmiş ya da terk edilmiş hissetme, uzaklaşma, önyargılı olma eğiliminde ve kontrol etme ihtiyacında artış olarak kendini gösterebilir (DBE, Erişim: 21.01.2019).

\section{Tedavi}

Travma sonrası stres bozukluğunun tedavisi iki türlü gerçekleştirilebilmektedir. Bunlar psikososyal tedaviler ve farmakolojik tedavilerdir. Travmanın şiddeti veya hastanın kişisel etkenlerine göre tedaviler den birisi veya ikisi beraber yürütülebilmektedir.

Travma sonrası stres bozukluğu hastalarına uygulanan Bilişsel Davranışçı Terapi (BDT) normal stres yanıtı hakkında eğitim, yanlış inanışları değerlendiren bilişsel terapi, gevşeme ve anksiyete kontrol teknikleri, travmayla alakalı uyaranlara yüzleşme ve nüks önleme tekniklerinden oluşmaktadır. Kaygı Yönetimi anksiyeteye bağlı kişinin günlük işlevleri bozulduğunda, gevşeme, rahatlama, bilişsel yeniden yapılandırma, olumlu telkin, düşünme durdurma tekniklerden oluşur. Sanal gerçekliğe maruz bırakmada ise kişilere görsel ve işitsel olarak uyaranlar gönderilerek travma durumuna benzer bir durumla yüzleștirilir (Gabbard, 2007, s. 27). Daha önce yapılan çalışmalarda ilaç tedavisinin TSSB'de ilk seçenek olmadığı, psikoterapilerle bütünleştirilmesi gerektiği ve terapilere ek olarak verilmesiyle ilgili genel bir kanı vardır (Shalev, Bonne ve Eth, 1996, s. 177). 
Kişinin tedavisinde ilaç kullanılması kararı verildikten sonra bu konu hastayla konuşulmalı ve ilaç tedavisinin gerekliliği hastaya anlatılarak işbirliği sağlanmalıdır. Travmaya uğramış kişi zaten kendisi ve çevresi üzerinde kontrolünü kaybettiğinden dolayı iyileşmesinin kendisi dışındaki yabancı bir etkene bağlı olması düşüncesi kişide bazı kaygılara sebebiyet verebilir. İlacın son çare olarak görülmesi düşüncesi kişide umutsuzluğu arttırabilir. Kişiye ilaç tedavisinin diğer tedavileri yanında bir basamak olarak düşünüldüğü anlatılmalıdır (Akçay, 2011, s. 26).

Travma sonrası stres bozukluğunda ilaç kullanmanın hedefleri şu şekilde sıralanabilir (Davidson, 1997, s. 30):

- Ortaya çıkan belirtilerin şiddetinin ve sıklı̆̆ının azaltılması,

- Kişiyi rahatsız eden uyaranların travmanın tekrarlanma olarak yorumlanma eğiliminin azaltılması,

- Travmayı anımsatan uyaranlara aşırı uyarılmış yanıtının verilmesinin azaltılması,

- Kaçınmanın azaltılması,

- Depresif duygu-durum ve küntleşmenin düzeltilmesi,

- Psikotik ve disosiyatif belirtilerin azaltılması,

- Kendine ve başkalarına karşı dürtüsel saldırganlı̆̆ın azaltılması.

Bunların yanı sıra sosyal desteğin sosyal ve fiziksel ve ruhsal sağlığın korunmasında önemli bir faktör olduğu ve stresli olaylarla başa çıkmada kişileri bu kaygının yıkıcı etkilerinden koruduğu belirtilmektedir (Dunn, Burbine, Bowers ve Tantleff-Dunn, 2001, s. 41). Kişilerin arkadaşlarından ve ailelerinden aldıkları sosyal destekle yalnızlık ve depresif hisleriyle daha iyi başa çıktıkları görülmektedir. Travmatik olaylar sonrasında verilen tepkiler incelendiğinde bekar, dul veya yalnız bireylerin sosyal desteğin yetersizliği nedeniyle stres tepkilerinin daha fazla olduğu gözlemlenmektedir. Sosyal desteği fazla olan kişilerin stresli durumlara daha çabuk uyum sağladığı ve hastalıkların iyileşmesinde olumlu etkisi olduğu belirtilmektedir (Sayıl, Berksun, Palabıyıkoğlu, Özgüven, Soykan ve Haran, 2000, s. 56: Arslantaş, Ergin, 2011, s. 138).

\section{Yöntem}

$\mathrm{Bu}$ araştırma nitel bir araştırma olup yarı yapılandırılmış görüşme tekniği kullanılmıştır. Nitel araştırmalar çıktılardan ve ya sonuçlardan daha çok süreç ile alakalıdır. Bu nedenden dolayı içerik önem taşımaktadır (Yılmaz ve Altınkurt 2011: 638). Yarı yapılandırılmış görüşmeler sağladıkları esneklik nedeniyle testler ve anketlerdeki sınırlılı̆̆ı ortadan kaldırır ve belirli bir konuda derinlemesine bilgi edinmeye yardımcı olmaktadır (Yıldırım ve Şimşek, 2005). Yarı yapılandırılmış görüşmeler ne tam yapılandırılmış görüşmeler kadar katı ne de yapılandırılmamış görüşmeler kadar esnektir, ikisi arasındandır. Bu esneklikten dolayı yarı yapılandırılmış görüşme tekniği kullanılmıştır.

Görüşme yapılacak kişilerin kaza sırasında madende bulunmuş olmaları ve araştırma için gönüllü olmaları şartları göz önünde bulundurularak seçilmesine özen gösterilmiştir. Araştırma grubunu toplamda 8 maden işçisi oluşturmaktadır. 
Araştırmaya ilişkin veriler, kazadan sağ kurtulmuş maden işçileriyle yüz yüze yapılan görüşmelerle toplanmıştır. Görüşmeler katılımcıların izni alınarak ve bu araştırmanın sadece bilimsel amaçlar için kullanılacağı ve katılımcıların kimliklerinin gizleneceğini söylenerek ses kaydına alınmıştır. Görüşmecilere kazadan sonra yaşadıkları süreci anlayabilmek için toplamda 10 soru yöneltilmiştir.

Mülakat tekniği kullanılarak veri toplanmaya çalışılan bu araştırmada verilerin analizinde içerik analizi tekniği kullanılmış ve elde edilen veriler gerekli görüldüğü noktalarda sayısal veriler haline dönüştürülmüştür. Görüşmelerde elde edilen katılımcıların ifadeleri doğrudan alıntı olarak kullanılmıştır.

Katılımcılarla gerçekleștirilen görüşmeler gizlilik esasına dayanarak, isimlere yer vermeden kodlanarak önce ses kayıtlarından bilgisayar ortamına aktarılmıştır. Sağ kurtulan işçileri ifade etmek için " $G$ ” ifadesi kullanılmış ve her ifadenin yanına "G1, G2, G3, ..." şeklinde numaralar verilmiştir.

Bütün görüşme kayıtları üç ana tema altında incelenmiştir. Bunlar Travma sonucu oluşan problemler, kaza sürecinde yaşananlar ve İş Sağlığı ve Güvenliği eksiklikleridir. Travma sonucu oluşan problemler temasının altında da fiziksel problemler, psikolojik (ruhsal) problemler, psikososyal problemler olmak üzere üç tane alt kategori vardır. Aynı şekilde Kaza sürecinde yaşananlar temasının altında da ölümü kabullenme, hayatta kalma mücadelesi, arkadaşların kaybı ve ana yola ulaşma çabaları olarak dört alt kategori mevcuttur.

\section{Bulgular ve Yorum}

\section{Travma Sonucu Oluşan Problemler}

Yaşanan bir travmanın psikolojik sonuçları olabileceği gibi fiziksel ve psikososyal sonuçları da olabilmektedir. Görüşmecilerin yaşadıkları travmadan ne gibi hasarlar aldıkları bu üç kategori altında ayrı ayrı incelenmiştir.

\section{Fiziksel Problemler}

$\mathrm{Bu}$ alt kategorinin içerisinde görüşmecilere kaza sırasında fiziksel yara alıp almadıklarını sorduğumuz da aldığımız cevaplar yer almaktadır. Görüşmecilerin bu kategoride yer alan bazı referans ifadeleri;

"Hastanede yoğun bakımda 1 hafta kadar yattım. Kazadan öncede kulaklarda sorun vardı ama travmadan sonra kulaklarım \%60 duymuyor." G1

"Hastaneye gitmedik ama dumanın etkisi vardı." G3

"Kazadan yara almadım. Zaten kazada yara alan diye bir şey yok ya orda ölen var ya da kurtarlanlar var." G4

"Fiziksel olarak yaralanma yoktu hastanede saat 11 çıktıysam 5-6 saat durdum. Oksijen falan verildi. Başka yapılan bir şey olmadı." G5 
Görüşmeci 1 hariç diğer görüşmecilerde dumandan etkilenme dışında kalıcı bir fiziksel yaralanma meydana gelmemiştir.

\section{Psikolojik (Ruhsal) Problemler}

Yaşanan travmanın psikolojik sonuçları görüşmecilerde kendisini psikolojik destek görme ihtiyacı, alkol kullanımı, kötü rüyalar, uyku problemi vb. şekillerde göstermiştir. Görüşmecilerin bu kategoriye uyan referans ifadeleri şu şekildedir;

"Destek almak için psikoloğa gittim ilaç kullandım. Ama ilaçlarda insanı ruh gibi yapıyor daha sonra ilacı da bıraktım." G1

"Psikolojik olarak hep böyle iyi miydim bilmiyorum eşim daha iyi bilir. Alkol alırdım normalde de ama o zamanlar içip mezarliğa giderdim. Mutlaka her gün içsem her gün giderdim hiçbir şey düşünemiyorsun zaten..." G2

"Uykuyla hiç barışık değildim. Uyumayı çok istiyorsun bazen ama uyuyamıyorsun. Sebebini bilmiyorsun galiba kazadan sonra arttı. İzmir'e gittim uyku apnesi dedi doktor. Benim kendimde en büyük hatam bence psikolojik destek almamak oldu. Benim görüşmem gerekiyormuş diye daha sonra çıktı etkisi. Oğlum oldu 2 yaşında o ortada gezerken aklıma geliyor onların babaları artık yok ben orda kopuyorum işte." G2

"İsyerine bu olaylar olduktan sonra gitmedim psikolojik olarak etkilenmeyeyim diye ama yine de insan etkileniyor psikolojik etkileri var." G3

"Yıldönümlerinde kabristana gitmemeye uğraşıyorum gittiğim zaman orda ben çok arkadaşımı kaybettim 10 senelik arkadaşlarımı kaybettim vefat edenler içinde çok etkileniyoruz yani.” G3

"Normal hayatta ben bir tane ölü görünce korkan insanım ama orda 240 tane cenazeyi çıkardım neler gördüm ama hiç etkilenmedim. Çünkü bir mücadele için girdik oraya arkadaşlarımızı çıkaralım diye kurtaralım diye. Kişisel etkilenmem değil ama burada toplumca etkilendik bence. İnsanların yoğun bir ilgisi oldu medyanın milletvekillerinin, dünyanın bir ilgisi oldu. İnsanlar hep arkalarında duracaklar sandılar, güvendiler sonra herkes çekilince kenara herkes bir boşlukta hissetti kendini." G4

"Psikolojik destek almadım. Yardım almadım bana ulaşılmaya çalışıldı isterseniz psikolojik destek verelim diye aradılar yardımlar için arandı ama ben almak istemedim. Ama psikolojimizi zor düzelttik kolay değildi. Geceleri kazayı hatırlatan rüyalar gördüğ̈̈m oldu. Sabaha karşı rüyalardan uyandığım oldu. Yedi seneden beri birlikte çalıştı̆̆ım arkadaşlarımızı gördüğüm oldu rüyalarda. Dediğim gibi psikolojik destek almadım ama kendi kendime bir şeyleri düzeltmeye çalıştım. Çocuğumuzla ailemizle beraber düzelttik.” G5

"Rüyada görmedim uyku problemi de yaşamadım. Psikolojik destekte almadım. Kimileri daha ă̆ır geçirdi ama ben öyle bir sorun yaşamadım." G6

“Psikolojik olarak hala kötüyüm antidepresan kullanıyorum." G7 
"Ben fazla bir şey yaşamadım ama psikolojik destek aldım tabi ki. 11 senelik arkadaşlarım öldü benim devaml yan yana birlikte olduğumuz arkadaşlarım öldü. Hala daha inanamıyorum öldüklerine bizim ekipten bir kişi öldü en sağlam dediğimiz arkadaşımız öldü. Onu unutamıyoruz tabi ki. Bunu yıllar geçse de unutamayacă̆ız. Somada destek aldım gezmeyle tozmayla bir şekil de atlattık. Uyku problemi de yaşadık ama hayat devam ediyor.” G8

\section{Psikososyal Problemler}

$\mathrm{Bu}$ kategoride ise görüşmecilerin kazadan sonra sosyal olarak yaşadıkları sıkıntılar yer almaktadır. İşsiz kaldıkları dönemlerde yaşadıkları maddi sıkıntılar ve tekrar iş bulmada yaşadıkları sıkıntılar vb. Görüşmecilerin bu kategoriye ait referans cümleleri;

"Psikolojik destek görenler işe alınmayacak diye söylenti duyunca bizde ilaçları elden almaya başladık eve gelen sağlık görevlileri de kesinlikle evde yalnız bırakmayın dediler. Tekrar madene girmek istedim ama kulaklarımdan dolayı almadılar. Çok zor iş buldum.” G1

"Evet, çalışıyorum ama maden sektörü değil normal şirketlerde günlük işçi olarak çalışıyoruz. Kazadan sonra 2 sene çalışmayacaktım ama baktım hayat şartları elvermeyince de mecbur kaldım." G3

"Olaydan iki sene sonra tekrar madene girdim. O süre zarfına kadarda 1 süre çalışmadım. Sonra bir sene çalıştım. Yani bir sene işsiz durdum. Bir yere girip çalışasım yoktu. 6, 7 ay kendimi zor düzelttim zaten. Hiçbir yerde çalışmayı düşünmedim." G5

"Şuan işsizim iş bulamıyorum. Çalışmak istiyorum ama iş yok." G7

-Tekrar madene giren görüşmecilerin ifadeleri;

"Zorluk şöyle aklına geliyor arkadaşların ama sonra toparliyorsun kendini kendi kendine yenmeye çalışıyorsun onlar yoklar artık gibisin den." G2

"Şimdi maden de çalışıyorum yine o olayı hatırlatan şey yapan yerleri var bu madende de. Bir şey olacak mı yine olacak mı diye korku var. İlk madene girmek istediğimde 6 ay önce ilk başta giremedim madene. İş almaya gittim madene gel başla dediler ama o zaman gözüm kesmedi. Girmeyeceğim dedim yapamayacağım dedim gitmedim madene. Daha sonradan hayat şartları zor mecbur kaldık. Sonradan tekrar yapacak bir şey yok tekrar iş başvurusu yaptık girdik yeraltına. Yeraltında olayı çağrıştıran ne bileyim hatırlatan şeyler oluyor o olay aklımıza geliyor ürperiyoruz ama tabi mecbur çalışıoruz. Yeraltı ortamı yine aynı tabi insana hatırlatıyor. Maden madene benziyor. Bir tek arkadaşlarım değişik birazda yaptı̆̆ın iş değişik." G5

"Mecbur geçinmek için girdik ama burada ki disiplin on numara. Tekrar madene girmekte de çok zorlanmadım 3 tane çocuk var borcum var mecbur girdik." G8

\section{Kaza Süreci (Travma)}

$\mathrm{Bu}$ tema altında işçilerin madende kaza meydana geldikten sonra madenden çıkana kadar yaşadıkları olaylara yer verilmiştir. Bunlarda arkadaşların kaybı, hayatta kalma mücadelesi ve maden havasının yönünün değiştirilmesi alt kategorilerinde ayrı ayrı incelenmiştir. 


\section{-Arkadașların Kaybı}

"Duman etkisiyle kimileri kendini kaybetmeye başladılar. Biz o bayılanları ayağa doğru çekmeye başladık. Saat ilerledikçe bayılanların sayısı artamaya başladı. Herkes kendi başının çaresine bakmaya başladı. Bende yere düşünce baktım ki uyku basar gibi oldu ama içimden bir ses hareket etmelisin dedi. Ama belden aşağısı tutmamaya başladı ama durduğum yerden çıktım. Gaz maskesini taktım ama zaten ben onu ilk patlamada açmıştım o yüzden bir etkisi yoktu ama yine de taktım ilerlemeye başladım. Yolda giderken can çekişen arkadaşlarımı gördüm. Kurbanı kesersin hayvan tepinmeye başlar ya aynı şekilde çırpınan insanlar vardı." G1

"Benim aklımda çocukluk arkadaşım var herkesi düşünüyorsun ama herkesin aklında tek isim olur orda bandin altından geçtim S panosu 3, 5 saniye ya sonra orda birisine onu sordum. Sonra oradan 3, 4 kişinin kolunda çocukluk arkadaşım arka taraf tepeleme insan yı̆̆ını ondan sonra ben onu aldım. Başka bir arkadaşımla birlikte götürdük ambulansa kadar hatta parmağında yüzüğ̈̈ vardı sağlıkçı alacaktı bırak kalsın dedim ambulansa bindirdim. Başka bir arkadaşım oradaydı. O gitti dedim anlamadı durdu ne diyorsun dedi sarstı beni." G2

"Benim olduğum yerde telefon vardı amirlerimle telefonlaşıyorduk. Yaşayıp yaşamadiğımızı sorumlu amirlerimize saat başlarında arayıp bildiriyorduk. 6 saat falan içerde kaldım işte bir sığınma bölgesinde hava olduğu için yaşadık. Diğer aşağıda çalışma bölgesindeki arkadaşlarımız kısa zaman içerisinde vefat ettiklerini taki ilk yardım ekibi geldikten sonra öğrendik.” G3

"İlk inenlerdenim zaten aşağıya içerde büyük bir katliam vardı. Cenazelerin üstüne basarak aşağılara indik insanları kurtarmaya.... Ben o gün tam 187 tane cenaze çıkardım.” G4

“Çıkarken hep arkadaşlarımın cesetleri üzerinde geçtim.” G7

"11 senelik arkadaşlarım öldü benim devaml yan yana birlikte olduğumuz arkadaşlarım öldü. Hala daha inanamıyorum öldüklerine bizim ekipten bir kişi öldü en sağlam dediğimiz arkadaşımız öldü. Onu unutamıyoruz tabi ki. Bunu yıllar geçse de unutamayacağız." G8

Madencilerin yeraltında beraber çalıştıkları arkadaşlarının can çekişmelerini ve ölümlerini görmüş olmaları, travmadan bu derece etkilenmelerine neden olan faktörlerden en önemlisi olarak gösterilebilir.

\section{-Hayatta Kalma Mücadelesi}

"Ben o ara yerde komşumu gördüm gaz maskesini yeni açtım takmaya çalışıyor ama takamıyor ben kendi maskemi çıkardım onun la konuşmak için o sırada duman daha da etkiledi beni kendimi kaybettim. Oradan geçen şefimizi gördüm yardım etti onunla omuz omuza çıkışa doğru gittik. Yürüyecek dermanım kalmayınca şefe işaretlerde daha fazla ilerleyemeyeceğimi söyledim hakkını helal et dedim sonra o ilerledi ben bir iki adım attım yere düştüm yerde emeklemeye başladım. Ana yolda durmaya çalıştım ölürsem de beni bulabilsinler diye. Sonra karşılaştığımız beşaltı arkadaşla istim tıpalarını çıkardık oradan sırayla temiz hava aldık. Daha sonra biz orda ekipler gelene kadar orada kaldık. Sonra ekipler yardımıyla dışarıya çıktık. Ama biz işin ciddiyetini geçtiğimiz yollardaki ölülerden anladık.” G1 
"duman bizim oraya da gelmeye başladı. Tabi duman yukarlarda biz aşağı̆da durduk biraz istim boruları var içinde hava var. Duman bizi etkilemeye başlayınca testeresi olan arkadaşlardan testereleri alı istim borularını kestik. Bu boruların içinde de yeryüzünden basılan havalar var basınçla çalışan aletler için. Bir müddet te bu borulardaki havalarla yaşamaya çalışıtı üç kişi bir havanin başına geçti ü̧̈ kişi diğerinin tabi o da elektrikler kesilince onlarda kesildi. Aşağıda bir baca daha varmış emniyetçiler baraj yapmışlar. Baraj dediğim de havanın yönünü kesmişler havayı diğer tarafa aktarmışlar belirli bir alan kalmış. Oradan sesler geldi buraya gelin diye bu sefer oraya indik oradaki havayla 142 kişi kadar orada durduk saat sekiz buçuk dokuza kadar. Orada ki havayla yaşadık. Belirli bir müddet yaşadık ama daha sonra havanın yönünü değiştirdiler. Onda sonra oradaki oksijende bitmeye başladı. Hava yönü değişince duman bize doğru gelmeye başladı. Millet kaçışmaya başladı ama zaten dermanımız fazla kalmamıştı. Gidebildiğimiz yere kadar gittik ondan sonra düştük zaten sonrasinı da çok fazla hatırlamiyorum. Sonra kurtarma ekibi geldi herhâlde biraz kendime geldim ayran su falan içtim." G5

Görüşmecilerden bazıları dumandan etkilendikleri için istim borularını keserek kendilerine az da olsa oksijen sağladıklarını ve böyle hayatta kaldıklarını ifade etmişlerdir.

\section{-Maden Havasının Yönünün Değiștirilmesi}

"Tabi biz kendi çabalarımızla gelmedik hava yönünü değiştirdiler kurtarma ekibi içeri girdi. Bize dışarı çıkabilirsiniz dediler öyle çıktım ben. Bizim bulunduğumuz yer tabi ki çıkışa daha yakındı vefat eden arkadaşlar daha derindeydi, çalı̧̧ma noktasinda üretim bölgesindelerdi ben nakliye yolunda olduğum için bantlarla kömür geldiği için nakliye bandının 2. Bandının motor başındaydım. Ana yolun avantajını kullanarak yardımla dışarı çıtık." G3

"Bir yönden iyi etkiledi bir yönden kötü. İyi etkiledi çünkü bizi kurtarmaya gelebildiler havanın уӧnünü değģş̧tirmeseler bizi kurtarmaya da gelemeyeceklerdi. Kurtarma ekibi içeri giremezdi çünkü olay ana yolda oldu duman bütün ocağ dolaşıyor yukarı çıkıyor. Havanın yönünü değiştirdiler. Ocağın havasın temizlemiş oldular. Ama işte yön değişince bizim bulunduğumuz yerlere de duman doldu. Ama hizl hareket edip bizi kurtarmaya geldikleri için 142 kişiden neredeyse hepsi kurtarıldı. Tabi ölenlerde oldu içerisinden." G5

"Yedi gibi mekanize ayak dediğimiz yerden arkadaşlar çıktı bizi çağırdılar oraya gittik. Orda kalabalıkmışsaydılar 140 kişi çıktık. Oralarda dolaşırken iki üç arkadaş düştü. Biz bu sefer biraz daha mekanizenin içine girdik. Orda oturduk düşmüşüm ben zaten bayılmışım daha sonra havayı tersine çevirmişler. Havayı tersine çevirince biz biraz ayılmaya başladık. Daha sonra çıkışa doğru arkadaşlarla birbirimize yardım ederek çıkışa doğru gittik." G8

Maden havasının yönünün değiştirilmesini olay sırasında maden içerisinde bulunanlardan bazıları için faydalı olsa da kimilerini de olumsuz etkilemiştir. Görüşmecilere göre havanın yönünün değiş̧irilmesi kurtarma ekiplerinin onlara ulaşması için gerekli olmuş olsa da dumana karşı bariyer kurup bekleyen iş̧ileri de bir o kadar kötü etkilemiştir. Maskeleri çok önceden açmış iş̧ileri duman içerisinde bırakarak onlara zor anlar yaşamalarına sebebiyet vermiştir. 


\section{-Madendeki İSG Eksiklikleri}

Görüşmecilerle gerçekleştirilen konuşmalar sırasında madendeki İSG eksiklikleriyle ilgili ipuçları elde edilmiştir. Bunlar gaz maskelerinin yetersizliği veya bozuk çıkması, kişisel koruyucu donanımların yenilenmesinde sıkıntı yaşanması, İSG eğitimleri ve maden denetlemesi vb. konularıdır. Bu konularla ilgili görüşmecilerin referans cümleleri şu şekildedir;

"Ben o ara yerde komşumu gördüm gaz maskesini yeni açtım takmaya çalışıyor ama takamıyor ben kendi maskemi çıkardım onun la konuşmak için o sırada duman daha da etkiledi beni kendimi kaybettim." G1

$\mathrm{Bu}$ cümlede bahsedilen "takmaya çalışıyor ama takamıyor" kısmıyla maden işçileri arasındaüzerlerine zimmetlenen maskeleri kullanmayı bilmeyenlerin olduğu kanısına varılabilir.

"Elbisemizi çizmemizi her şeyimizi de veriyorlard. Eldiven çizme çabuk eskiyordu onları tekrar alırken sorun yaşıyorduk. Giden arkadaşların eşyalarıyla falan değiştiriyorduk.” G1

"Şirketin, devletin kuralları dışında yaptığı bir şey yok kanun neyse onu yapıyorsun, gaz maskesi diyor alıp veriyorsun. Maskeyi alı teraziye koyuyorsun 10.22 diyor mesela ona çok iyi diyorsun. A ̆̆ırlığı tam çıkarsa adama verip kullandırıyorsun içini açıp bakma imkânı yok açtı̆̆ın an bitiyor. Devlet bunu koymuşvatandaşta bunu kullanıyor, patron bunu kullanıyor devlet ne kural koyarsa patron onu yapiyor." G2

"Bize maske veriyorlardı ama bunları kontrol ederken de içini açıp bakma durumu olmadı̆̆ından sağına soluna bakıp bize veriyorlardı bizde sağlam diye yanımızda taşıyorduk. Benim kullanmaya fırsatım olmadı ama daha aşağıdaki arkadaşlarım kullanmışlar.” G3

"Maske olayı önceden sadece bir toz maskesi gibi dışarıdan gelen tozu engelleyen başka özelliği olmayan maskeler vardı. Ki zaten benim kazadaki maskemde küflü çıkmıştı kullanamamıştım. Onu açmıştım olay günü bir ümit ama kullanamamıştım. O maskelerde zaten dışardaki oksijeni dumandan tozdan süzüp sana hava sağlıyor. Dışardan alıyorsun yine havayı bizim olay olduğunda dışarda oksijen olduğunu sanmıyorum." G5

"Kişisel koruyucu donanım veriyorlardı üzerimize zimmetliyorlardı. Benimkiler sorunlu çıkmadı ama maskesi bozuk çıkan arkadaşlarım hep o yüzden öldü.” G7

"Şuan ki elimizde ki gibi maskeler yoktu mesela. Eğitimimizi aldık ama dumanın içindesin istediğin kadar eğitim al ne olacak eline bir şey vermedikten sonra. O kazada şimdiki gibi maskeler olsayd o kadar insan ölmezdi. Ama kaza sırasında elimizdeki maskelerde yarı yolda kalacă̆ımızı bildiğimiz için gidemedik.” G8

Görüşmeci2 ve Görüşmeci3’ün bahsettiği o dönemde verilen ve kullandırılan gaz maskelerinin kontrollerinin hiçte sağlıklı olmadığı sonucuna varılabilir. Çünkü Görüşmeci5’in maskesinin küflü çıkması çok nadir gerçekleşmiş bir olayda olsa maskelerin sağlamlık kontrolünün güvenirliliğine şüphe düşürebilecek nitelikte bir olaydır. Eskiyen kişisel koruyucu donanımların 
değişimleri sırasında sorun yaşadıklarını ve hatta işten ayrılan arkadaşlarıyla eşyalarını değiştirdiklerini söylemişlerdir.

"Zaten madeni denetleyen kişi devletin gönderdiği kişiler maaşı şirketten alıyor. Şirketten maaş alan insan şirketi ne derece etkileyebilir. Bize yazı geliyordu mesela emniyetçilere bir hafta sonra şu gün şu saatte şurada ocak denetlenecek deniliyordu. Bizde bize verilen emirlere uyarak emniyetsiz çalışılan yerleri kapatıyorduk. Denetlenecek yerler temizleniyordu talaşlar falan atılıyordu, çamurlar temizleniyordu her şey dört dörtlük oluyordu. Sadece anayolu denetliyordu. Asıl kömürün çıktığı asıl tehlikenin olduğu yerlere bakmıyordu bile yani göstermelik geliyordu maaşı da şirketten aldığı için aksi bir şey yazma gibi şansı yoktu.” G4

“Ölçümler falan göz ardı ediliyordu devamlı emniyetçi dolaşmıyordu. Devamlı ölçüm yapan aletler çalışıyor muydu çalışmıyor muydu bilmiyoruz. Şimdikiler direk yerüstüne bağlı herhangi bir şey olduğunda direk yerüstünden görülüyor. Herhangi bir oksijen azalması veya karbon monoksit çoğalmasında yerüstünde nerde sorun olduğunu hemen görüyorlar. Eskiden bunlar yoktu herhalde." G5

Madende yapılan ölçümlerin ve denetlemelerin yetersiz olduğu yapılan denetlemelerde de önceden haber alındığı ve denetlenecek alanların kurallara uygun hale getirildiği söylenmiştir.

\section{-Eğitimler}

"Kaza olan madene girerken 2008 in ilk ayında eğitim almadım. Orda öyle bir eğitim almadım. Işse giriş eğitimi dediklerinde sana dışarda ă̆ır taşıtıyorlardı işi yapabiliyor musun diye. Ĕ̆itim aldım diye imza atıyordun." G5

\section{“Aldık eğitimler ama yetersizdi." G7}

"Eğitim şudur mesela kadın mahkemeye gelmiş benim kocamın okuması yazma yoktu nasıl geçti sınavı diyor. Evet, doğru ama geçmediği zaman kapı aşındırıyorsunuz iş verin diye. Eğitim adam geliyor tahtada anlatıyor yeni gelen kimse anlatılmıyor değil anlatılıyor ama ne bekliyorsun ki üniversite mezunu değil ki nasıl anlasın şuan İSG sınavı yapılsa iş̧̧iyi bırak emniyetçilerin bile \%50si geçemez. Eve şimdi bir tık ileri geçti ama yeterli değil bence maden de çalışacak adamın en az lise mezunu olması lazım, en az o adamın okuma yazması olması lazım, anlaması lazım. Bence madenin hiçbir zaman tam anlamıla her şeyinin bilmesi imkansız." G2

İşçilerle yapılan görüşmelerde eğitim konularında bazı işçilerin eğitim almadıklarını ifade etmişlerdir. Madende çalışan işçilerin eğitim düzeyinin düşük olmasından dolayı verilen eğitimlerin yetersiz olduğu ve hatta okuma yazma bilmeyen işçilere eğitim verildiğine dair imza alındığı görüşmeler sırasında dile getirilmiştir.

\section{-Madende meydana gelen yangınların sıklığı}

"Biz ek yapılan kablolar patladı diye tahmin ettik. Biz arkadaşlarla birlikte mekanizenin kaçamağına gittik. Ama biz yine ufak bir sorun gibi tahmin ediyoruz önce mavi beyaz gibi bir duman geldi sonra duman koyulaşmaya başladı." G1 
Görüşmecil'in ifadesinden yola çıkarak madende kullanılan elektrik kablolarına ek yapıldığı ve daha önce bu kısımlardan yangın meydana geldiği sonucuna varabiliriz. Böyle bir olay daha önce yaşanmamış olsaydı işçiler böyle bir tahminde bulunamazlardı.

"Normal bir günde çalışırken, normal vardiyadayız, her şey normal 14.45 te uzak bir noktada trafo patladı diye bize söylendi. Trafo olayının pek uzun sürmediğini bildiğimiz için sonradan geri bir daha telefonlaşamadık amirlerimizle. Bize normal bekleme süresi verildi.” G3

"O madende emniyetçi olarak çalışıyordum. Her gün yangın çıkıyordu. Ocă̆ın her yanı yanıyordu. Benim işimde emniyetçi olduğu için yangınları söndürmekti görevim. Cihazlar ötüyordu işte gaz ölçüm cihazları yani burada çalışılmaz diye uyarıyordu insanları bizde bunu görüyorduk amirimize söylüyorduk şef burası ötüyor burada nasıl çalışsın insanlar diye bir şey olmaz çalışın diyordu." G4

Görüşmeci3 ve görüşmeci4'ün ifadelerinden yola çıkarak madende çıkan ufak çaplı yangınlara alışı oldukları bunun gibi olayların sık sık olduğunu ve hatta bu gibi durumlar için işçilere bekleme sürelerinin verildiği ifadelerini kullanmışlardır.

"Kazanın olacă̆ını biliyordum hissediyordum. Daha fazla kömür çıkarmak hırsıyla insanlara sürekli hadi dersen böyle olur.” G8

"Sürekli yangınlar söndürüyorduk bir şeylerin olacağı belliydi kar hırsı para hırsı bir ayda bitecek yeri başımızdaki mühendise on bin lira verip 15 günde bitirmesini istiyorlardı. Tabi bu kadar kısa sürede bitirmeye çalışırsan işçilerde emniyetsiz çalışıyorlardı. Bu şekilde bir çalışma vardı yani yılda bir milyon ton kömür çıkaracaksan iki buçuk milyon ton çıkarılıyordu." G4

$\mathrm{Bu}$ iki görüşmeci görüşmeler sırasında fazla kömür çıkarmak amacıyla hızlı ve güvensiz ortamlarda çalıştırıldıklarını, madende kısa zamanda normalde çıkarılması gerekenden daha fazla kömür çıkarıldığını dile getirmişlerdir.

\section{Sonuç}

Soma maden kazasından sağ kurtulan işçilerin yaşadıkları sorunların belirlenmesi için yapılan araştırmada aşağıdaki sonuçlara ulaşılmıştır.

\section{Kazadan sağ kurtulanların sağlık sorunlarıyla ilgili sonuçlar Kazanın Fiziksel Sonuçları}

Görüşmecilerle yapılan konuşmalarda sadece Görüşmeci1 de kalıcı bir fiziksel hasar oluştuğu görülmektedir. Kazadan öncede var olan işitme problemi kazadan sonra daha da artarak yaşamını olumsuz etkilediği öğrenilmiştir. Bütün görüşmeciler kaza sırasında dumandan ciddi şekilde olumsuz etkilendiklerini ve madenden çıkarıldıktan sonra bir süre hastanede kontrol altında tutulduklarını söylemişlerdir.

\section{Kazanın Psikolojik Sonuçları}

Görüşmeciler arasından bu durumu hafif atlatanlar olduğu gibi bu süreci ağır geçirenlerde olmuştur bu durum kişiden kişiye çeşitlilik göstermiştir. Bu süreçte psikolojik desteğe ihtiyaç 
duyup antidepresan kullanan görüşmecilerin yanı sıra bu durumu kendisi ve ailesiyle atlatmaya çalışan görüşmecilerde olmuştur. Yaşanan olayın ortak olduğu göz önünde bulundurulursa bu sürecin kişilerde farklı şekillerde seyretmesi kişisel sebeplere bağlanabilir. Bunlarda psikolojik öykü, daha önceki travmalar ve kişinin stresle başa çıkma yollarının farklılıklarıdır. Travma sonrasında görüşmeciler uyku problemi yaşadıklarını ve bu durumları zor atlattıklarını söylemişlerdir. TSSB' nin klinik tablosunda yer alan yeniden değerlendirme aşamasında mağdurlar olayı zihinlerinde yeniden gözden geçirerek travmayla yüzleştikleri aşamadadır. Olayı istemsizce hatırlamaları veya rüyalarında görmeleri olayı kendi kendilerine kontrolleri altına almaya çalışmalarının bir göstergesidir. Kazadan sonra uyku problemi ve kâbuslar yaşadınız mı sorusuna 8 görüşmeciden 4 tanesi bu durumları yaşadıklarını söylemişlerdir. Görüşmeci2 alkol aldığı zamanlar sık sık mezarlığa gidip ölen arkadaşlarını ziyaret ettiğini, Görüşmeci3 ise özellikle kazanın yıldönümlerinde kazayı ve ölen arkadaşlarını hatırlattığı için mezarlığa gitmekten kaçındıklarını söylemişlerdir. DSM-IIIR ile birlikte TSSB' nin tanı kriterler arasına psikojenik amnezi, travmayla ilgili düşüncelerden kaçınma, geleceğin yok olduğu duygusu, irritabilite ve öfke eklenmiştir. Görüşmeci2’ nin alkollüyken, kaçındığı uyaranların ortaya çıktığı söylenebilir. DSM-III' teki belirtilerin bir sürekliliğinin olması kriterinin, Görrüsmeci2' nin'zamanında psikolojik destek almayışının kendisindeki en büyük hata olduğunu ve bunun etkilerinin sonradan çıktığı” yönündekiifadeleri ile oluştuğu ve sonucunda TSSB nin belirtilerinin görülmüş olduğu söylenebilir. Çeşitli sorunları belirli düzeylerde yaşayanların yanında Görüşmeci5 ve Görüşmeci6 gibi hiç etkilenmediğini ve bu süreci sorun yaşamadan atlattığını söyleyen görüşmecilerde olmuştur. Aynı olayı yaşamış olmalarına rağmen kazadan sonraki süreç kişiden kişiye göre farkllık göstermektedir. Toplam 8 tane görüşmeciden sadece 3 tanesi psikolojik destek aldığ diğer görüşmecilerin bu süreci kendi başlarına atlatmaya çalıştı̆̆ görülmektedir. Kazanın üzerinden dört yıl geçmesine rağmen görüşmecilerin olayın detaylarını ilk gün ki gibi hatırladıkları ve olayı unutamadıkları gözlemlenmiş̧ir.

\section{Kazanın Psikososyal Sonuçları}

Travma Sonrası Stres Bozukluğunun klinik tablosunu şekillendiren beş aşamadan birisi olan kaçınma aşamasında; mağdurlar sosyal hayatlarında kendilerine olayı hatırlatan her türlü uyarandan kaçınıp içine kapanarak korku, endişe, huzursuzluk ve anksiyetelerini azaltmaya çalışmaktadırlar. Yapılan görüşmelerde Görüşmeci3 ve Görüşmeci5'in cevaplarından yola çıarak bahsedilen bu belirtilerin görüldüğü dolayısıyla bu kişilerde Travma Sonrası Stres Bozukluğu belirtilerine rastlandığı söylenebilir. İşçilerin kazadan sonra özellikle işsiz kaldıkları dönemde maddi sıkıntılar yaşadıkları ve iş bulmada zorlandıkları anlaşılmaktadır. O dönemde ne kadar çalı̧̧ak istemeseler de maddi zorluklar yüzünden tekrar çalışmayı düşünmek zorunda kalmışlardır. Hatta başlarda zorluk çekseler de ölümden döndükleri maden ortamına tekrar girmeyi istemişlerdir. Tabi bu fikir değişikliğinde kazadan sonra maden çalışma koşullarının ve imkânlarının iyileştirilmesinin de büyük katkısı vardır. 8 görüşmeciden 6 tanesi tekrar madende çalışmak istediniz mi sorununa evet olarak cevap vermiştir. Görüşmeci5 ve görüşmeci8'in ise şuanda başka bir maden firmasında çalıştıkları öğrenilmiştir. Şuanda madende çalışmakta olduğunu söyleyen görüşmeciler şimdiki firmalarında çalışma disiplinin daha iyi olduğunu ve çalışma koşullarının eskiye göre çok daha iyileștirildiğini söylemişlerdir. 
Görüşmeci5 ikinci kez madene girerken çok zorlandığını, vazgeçtiğini ve daha sonradan tekrar deneyip girdiğini yer altında eski olayları ve arkadaşlarını hatırlayıp ürperdiğini ama çalışmaya mecbur olduklarını ifade etmiştir. Görüşmeci5’in bu sözleriyle kendi yöntemiyle uyaranlardan kaçınmaya çalıştığı söylenebilir fakat olay esnasında yaşadığı sıkıntıları hala girdiği ortamda tekrar tekrar hatırlaması TSSB göstergelerinden bir tanesidir.

\section{isG Sonuçları}

İşçilerin büyük çoğunluğu kaza sırasından dumandan büyük ölçüde etkilenmiştir. Kimi işçiler kirli havanın yukarda biriktiğini bildiklerinden dolayı etkilenmeyi en aza indirmek için zemine yakın konumda beklemişler, kimisi ise bu en temel bilgiyi bilmeden bunu kaza sırasında şans eseri tecrübe ederek öğrenmiştir. Bu da işçilerde ciddi bir eğitim eksikliğinin olduğunun göstergesidir. Aynı şekilde Görüşmecil'in bahsettiği maskesini takmasını bilmeyen arkadaşına yardım etmeye çalışması konusu da işçilere yeterli bilgilerin verilmemiş olduğunu destekleyen bir diğer önemli detaydır. İşçilerin kendi başlarına çıkmaya cesaret edemeyişlerinin bir nedeni de maskelerin ömrünün kısa oluşu yani maskelerin yetersizliğidir. Gaz maskelerinin tek sorunu sadece sürelerinin kısa olması değil aynı zamanda bu malzemelerin sağlamlık kontrolünün güvenirliliğinin yeterli olmamasıdır. Kaza esnasında tek bir maskenin bile küflü çıkışı bu güvenirliliği sarsmaya yetecek niteliktedir çünkü o ölümle mücadele sırasında her bir gaz maskesi bir insan için nefes anlamına gelmektedir. Görüşmeci4'ün madende gerçekleşen denetlemelerin önceden haber veriliyor olunması ve maden içerisinde de sadece denetlenecek alanların kurallara uygun hale getiriliyor ifadeleri madende eksiklerin saklandığını ve maden firmasının yönetiminde sorunlar olduğu ihtimallerini destekliyor. Görüşmeler sırasında yöneltilen eğitim aldınız mı sorusuna 8 görüşmeciden 6 tanesi evet olarak cevaplamışlardır. Kişisel koruyucu donanımınız yeterli miydi sorusuna da 8 görüşmeciden 4 tanesi evet olarak cevaplandırmışlardır. Görüşmecilerin ifadelerinden madende sık sık yangınların meydana geldiği ve işçilerin bu durumları artık olağan bir durummuş gibi karşıladıkları anlaşılmaktadır. Görüşmeci8 ve görüşmeci4 madende daha fazla kömür çıkarmak amacıyla güvensiz ortamlarda işçi çalıştırıldığını ifade etmişlerdir.

\section{Kaynakça}

Akçay B. D. (2011). Travma Sonrası Stres Bozukluğu Tanısı Alan Hastaların Uyku Yapısındaki Değişiklikler. Genelkurmay Başkanlığı Gülhane Askeri Tıp Akademisi Askeri Tıp Fakültesi Ruh Sağlığı ve Hastalıkları Anabilim Dalı Başkanlığı, Tıpta Uzmanlık Tezi. Ankara, 6-7.

American Psychiatric Association. (1952). Diagnostic and statistical manual of mental disorders (1st ed.) (DSM I). Washington, DC: Author, 48-49.

American Psychiatric Association. (1968). Diagnostic and statistical manual of mental disorders (2nd ed.) (DSM II). Washington, DC: Author, 40.

American Psychiatric Association. (1980). Diagnostic and statistical manual of mental disorders (3rd ed.) (DSM III). Washington, DC: Author, 236-239.

American Psychiatric Association. (1987). Diagnostic and statistical manual of mental disorders (3rd ed.,rev.) (DSM III-R). Washington, DC: Author, 12-13. 
American Psychiatric Association. (1994). Diagnostic and statistical manual of mental disorders (4th ed.) (DSM IV). Washington, DC: Author, 393-394.

American Psychiatric Association. (2013). Diagnostic and statistical manual of mental disorders (5th ed) (DSM V). Washington, DC: Author, 265.

Arslantaş, H. \& Ergin, F. (2011) 50-65 Yaş Arasındaki Bireylerde Yalnızlık, Depresyon, Sosyal Destek ve Etki Eden Faktörler. Türk Geriatri Dergisi, 14(2), 135-144.

Baltaş, A. \& Baltaş, Z. (1988). Stres ve Başa Çıkma Yolları (6. Basım), İstanbul: Remzi

Baysak E. (2010). Acil ve Yoğun Bakım Çalışanlarında Travma Sonrası Stres Bozukluğu, Stresle Başa Çıkma Tarzları, Tükenmişlik ve İlişkili Etkenler. Uzmanlık Tezi. Gazi Üniversitesi Tıp Fakültesi, Ankara, 22-23

Classen C.,Koopman C. \& Hales R. (1998). Acute Stres Disorder As A Predictor of Posttraumatic Stress Symptoms. Am J Psychiatry, 155, 620-624.

Davidson, J. R. (1997). Biological therapies for post traumatic stress disorder: an overview. The Journal Of Clinical Psychiatry, 29-32

DBE. Travma Sonrası Stres Bozukluğu nedir? 21.01.2019 tarihinde DBE davranış bilimleri enstitüsü: http://www.dbe.com.tr/Yetiskinveaile/tr/psikolojik-travma-ve-emdr/travma-sonrasi-stresbozuklugu-tssb-nedir/ adresinden alındı

Dunn, M. E.,Burbine, T., Bowers, C. A., \& Tantleff-Dunn, S. (2001). Moderators of stress in parents of childrenwithautism. Communitymentalhealthjournal, 37(1), 39-52.

Gabbard G.O. (2007). Gabbard'streatments of psychiatricdisorders. (4th ed.) Washington, DC ; London: AmericanPsychiatricPub., 27

Gersons, B. P. \& Carlier, I. V. (1992). Post-traumaticstressdisorder: Thehistory of a recentconcept. The British Journal of Psychiatry, 161(6), 742-748

Hacıoğlu, M., Gönüllü, O., \& Kambberyan, K. (2002). Travma Sonrası Stres Bozukluğu Tanısının Gelişimi Üzerine Bir Gözden Geçirme. Düşünen Adam, 15(4), 210-214.

Sayıl, I., Berksun, O. E., Palabıyıkoğlu, R., Devrimci-Özgüven, H., Soykan, Ç., \& Haran, S. (2000). Kriz ve Krize Müdahale. Ankara: Ankara Üniversitesi Psikiyatrik Kriz Uygulama ve Araştırma Merkezi, No.8, 56

Shalev, A. Y., Bonne, O., \& Eth, S. (1996). Treatment of Posttraumaticstressdisorder: A review. Psychosomaticmedicine, 58(2), 165-182.

World Health Organization. (WHO) (1993). The ICD-10 Classification of Mental and Behavioural Disorders: Diagnostic Criteria For Research. World Health Organization, 2, 119-121.

Yıldırım, K. E. (2019). Profesyonel Yöneticiliğin Kamu Yönetiminde Uygulanabilirliği. Kafkas Üniversitesi İktisadi ve İdari Bilimler Fakültesi Dergisi, 10(19), 576-589.

Yıldırım, A., \& Şimşek, H. (2005). Sosyal Bilimlerde Nitel Araştırma Yöntemleri. Ankara: Seçkin

Yılmaz, K.,\&Altınkurt, Y. (2011). Göreve Yeni Başlayan Özel Dershane Öğretmenlerinin Kurumlarındaki Çalışma Koşullarına İlişkin Görüşleri. Kuram ve Uygulamada Eğitim Bilimleri, 11(2), 638. 